\title{
Design of Performance Evaluation Index of Scientific Research Projects Based on BSC
}

\author{
Qiu Yu ${ }^{1 *}$, Peng Yan ${ }^{2}$ \\ ${ }^{1}$ Naval University of Engineering Department of Management Science and Equipment Economics, Wuhan, Hubei, China \\ ${ }^{2}$ Naval University of Engineering Department of Management Science and Equipment Economics, Wuhan, Hubei, China
}

\begin{abstract}
As the carrier of scientific research funding for various organizations, scientific research projects are the main driving force for the development and progress of national science and technology. Performance evaluation of these projects can stimulate the vitality of scientific research, and promote scientific and technological innovation. In order to establish and improve the performance evaluation system of military scientific research projects, this paper studies the performance evaluation indicators from four perspectives: resources, effect, internal business processes, and learning and growth based on the balanced score card.
\end{abstract}

\section{Preface}

Since the 19th National Congress of the Communist Party of China, in order to realize the strategy of scientific and technological innovation-driven development, my country has continuously increased its investment in scientific research funds. According to statistics from the National Bureau of Statistics, my country's basic research funds in 2018 and 2019 were 111.8 billion yuan and 2,173.7 billion yuan respectively. Such a huge amount of scientific research funds not only brings confidence to various scientific research units, but also puts forward higher requirements for scientific research management. Performance evaluation of scientific research projects can not only ensure that scientific research activities meet the project plan through effective communication, but more importantly, it can make reasonable measurements of project results, which is beneficial to stimulate innovation vitality. Based on the principles and methods of the balanced score card, starting from the strategic objectives of scientific research projects, this paper designs performance evaluation indicators that meet the characteristics of scientific research projects from four dimensions: resources, effect, internal business processes, and learning and growth.

\section{The Balanced Score card}

In 1990, Robert Kaplan of Harvard Business School and David Norton, director of the Nolan Norton Institute, formally proposed The Balanced Score Card theory on the basis of summarizing the management experience of many leading companies in performance ${ }^{[1]}$. The Balanced Score card proposes that organizations must consider how to obtain sustainable development momentum in terms of suppliers, employees, customers, organizational processes, technology and innovation, and so on. Therefore, organizations should examine their performance from four dimensions: financial dimension, customer dimension, and internal business. The process dimension, the dimension of learning and growth. For an enterprise, the financial dimension considers financing capacity, operating capacity, profitability, etc.; the customer dimension considers how to retain old customers, attract new customers, and market share; the internal business process dimension requires the company to strengthen Internal management pays attention to those key business processes; the learning and growth dimension is to pay attention to the employees of the company, requiring the company to pay attention to the training of employees' needs and abilities.

\section{The applicability of the balanced score card in the performance evaluation of scientific research projects}

The difference between scientific research projects and general projects lies in their innovation and uncertainty. Both the theoretical results and technical results of the project are difficult to accurately evaluate with monetary indicators, so the evaluation of scientific research results has always been the focus and difficulty of the evaluation of scientific research projects., And in some cases, the importance of evaluating the results of scientific research projects often exceeds the importance of the project itself. As a result, in the evaluation of scientific research projects, the common idea of determining evaluation indicators is to design indicators according to the general mode of "input-output" of scientific research projects. The advantage of this is that the ideas are simple and clear, and can reflect the evaluation of scientific research projects. It is important, but it is impossible to evaluate the overall

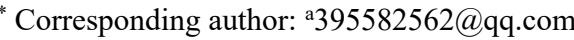


project. The goal of performance evaluation of scientific research projects is to evaluate the entire life cycle of scientific research projects, not just to evaluate the results. The core idea of the balanced score card is to grasp the core of corporate strategic goals and then establish an evaluation index system from the four dimensions of finance, customers, internal business processes, and learning and growth, and apply this idea to the performance evaluation of scientific research projects. It is to take the performance evaluation goal of scientific research project as the core, from the four perspectives of resource input, output of results, management process, and the impact of the project on individuals. These four perspectives not only include the main scientific research projects. The "input-output" link of the company also provides a perspective on project process and project impact, and realizes the overall evaluation of scientific research projects. Therefore, the balanced score card is applicable in the performance evaluation of scientific research projects.

However, the balanced score card was originally proposed for the performance evaluation of enterprises. If it is simply applied to the performance evaluation of scientific research projects, it is inevitable that the setting of performance indicators is unreasonable due to the different attributes of the evaluation objects, so the balanced score card is being used. Cards need to make appropriate adjustments before designing performance evaluation indicators for scientific research projects. First, the resource dimension is used to replace the financial dimension, because the analysis of scientific research projects from the financial dimension is more from the perspective of scientific research resources. The term "finance" cannot reflect the meaning of "resources" and is likely to cause ambiguity; Use the effect dimension instead of the customer dimension. For scientific research projects, the demand analysis based on the customer dimension is based on the effect of the scientific research project on the subject. Instead of analyzing the different needs of different customers, it is better to analyze the effect of the project that meets the needs of customers. It is straightforward; finally, the internal business process dimension and the learning and growth dimension are not adjusted because the scientific research project has a complete business process and can provide the participants with learning and growth conditions.

\section{Design of performance evaluation indicators for scientific research projects based on balanced score card}

\subsection{Principles of indicator design}

Regarding the construction of performance evaluation indicators for scientific research projects, it is necessary to take into account the particularity of scientific research projects while taking into account the general use of funds. When establishing indicators, it is necessary to make it clear that performance evaluation is an evaluation of the entire process, and adhere to the systematic principle of linking each link; the determination of indicators is not random but a purposeful principle with expectations; taking into account the cost efficiency and technological innovation, subjective evaluation The principle of balance with objective evaluation, quantitative indicators and qualitative indicators; the feasibility principle that indicator data is available and can be used in the next stage of performance evaluation; indicators can explain the importance of a certain aspect of scientific research funding rather than insignificant importance Principle ${ }^{[2]}$.

\subsection{Analysis of performance evaluation indicators of scientific research projects based on the balanced score card}

In this paper, the construction of the performance evaluation index database of scientific research projects is based on the theory of balanced score cards and analyzes from four dimensions, including resources, effect, internal business processes, and learning and growth.

\subsubsection{Resources dimension}

The innovation of scientific research projects determines that it is difficult for scientific research projects to be evaluated by monetary financial indicators such as profit margins. Moreover, the most important indicators selected for general projects are to reflect costs and benefits, but all activities related to scientific research projects are not purely economical. Compared with the economic income brought by the use of funds, the performance evaluation of scientific research projects is considering investment. At the same time, it pays more attention to the scientific research results after the resources are put into use. Therefore, for scientific research projects, the indicators of this dimension should be able to reflect the input of resources and the output of the project. In addition, as far as scientific research projects are concerned, the results are only the direct output, which can indicate whether the project is completed, but it cannot reflect the quality of completion. Therefore, while considering the output, indicators that can reflect the quality of the scientific output should also be added. For example, indirect output such as achievement awards. In simple terms, the design of performance evaluation indicators for scientific research projects in the resources dimension needs to consider two categories: scientific research input (including funds, manpower, material resources), scientific research output (including basic theoretical results, applied technology results, soft science results, achievement awards). Specific indicators are shown in Table 1

Table1. Performance indicators of the resources dimension

\begin{tabular}{|c|c|c|}
\hline Dimension & Category & $\begin{array}{c}\text { Key Performance } \\
\text { Indicators }\end{array}$ \\
\hline Resources & $\begin{array}{c}\text { Funding } \\
\text { Research } \\
\text { investment }\end{array}$ & $\begin{array}{c}\text { Hardware/software } \\
\text { investment } \\
\text { Scientific research } \\
\text { personnel input }\end{array}$ \\
\hline
\end{tabular}




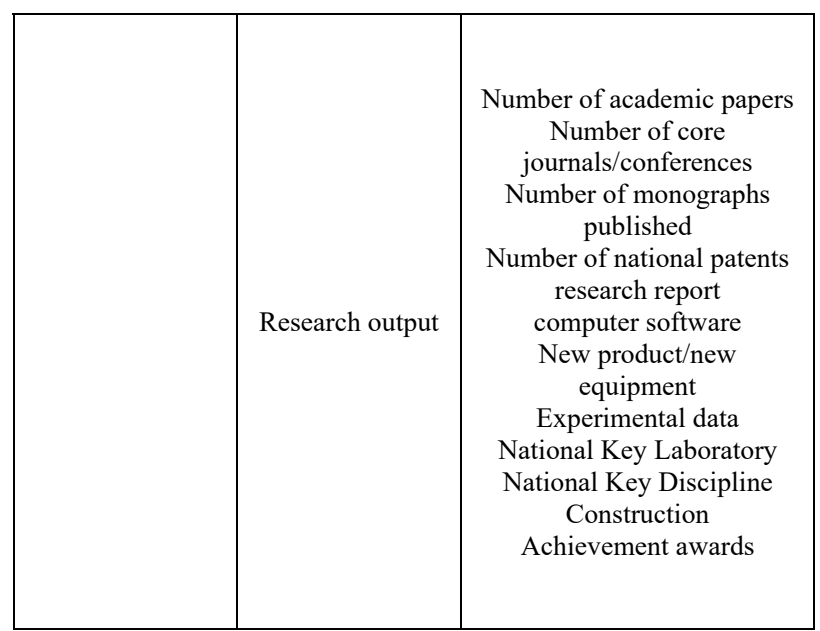

\subsubsection{Effect dimension}

For scientific research projects, the results often vary depending on the form of scientific research results. Scientific research achievements can be divided into three main forms: basic theoretical achievements, applied technology achievements, and soft science achievements. As far as the basic theoretical results are concerned, they are mainly new discoveries or new doctrines of theoretical innovation, and whether the theory can be used to guide practical activities; the form of applied technology results mainly considers whether the technology can be used in practice and to what extent. , The degree of technological innovation and advancement, etc.; soft science achievements are the theories and methods of research on policies and activities, which provide a basis for decisionmaking, and what needs to be considered is whether it is creative in theory and feasibility of practical application. Because the design of indicators for basic theoretical achievements and soft science achievements is based on theory, the two categories are combined into one category. Specific indicators are shown in Table 2

Table2. Performance indicators of the effect dimension

\begin{tabular}{|c|c|c|}
\hline Dimension & Category & $\begin{array}{c}\text { Key Performance } \\
\text { Indicators }\end{array}$ \\
\hline \multirow{4}{*}{ Effect } & Theoretical results & $\begin{array}{c}\text { Theoretical } \\
\text { creativity } \\
\text { Feasibility of theory } \\
\text { application }\end{array}$ \\
\cline { 2 - 3 } & & Technical test \\
& Technical & success rate (\%) \\
& achievements & application scope \\
& & Technology \\
& & conversion rate $(\%)$ \\
& & Technological \\
& & advancement \\
\hline
\end{tabular}

\subsubsection{Internal business process dimensions}

In the balanced score card, the internal business process dimension requires companies to pay attention to key business-related processes and improve internal management capabilities. Similarly, the establishment of performance indicators for scientific research projects in this dimension needs to be considered in conjunction with the key process of scientific research projects, respectively. Project establishment, project implementation and project acceptance. The indicators in the project approval phase should be able to explain the necessity and feasibility of the project ${ }^{[3]}$; the indicators in the project implementation phase should reflect the funding management and plan implementation; the indicators in the project acceptance phase need to explain the completion of the expected goals. The specific indicators are shown in Table 3:

Table3. Performance indicators of internal business process dimensions

\begin{tabular}{|c|c|c|}
\hline Dimension & Category & $\begin{array}{c}\text { Key } \\
\text { Performance } \\
\text { Indicators } \\
\end{array}$ \\
\hline \multirow{3}{*}{$\begin{array}{l}\text { Internal } \\
\text { business } \\
\text { process }\end{array}$} & Project approval & $\begin{array}{l}\text { Innovative } \\
\text { expected results } \\
\text { Project plan } \\
\text { rationality }\end{array}$ \\
\hline & $\begin{array}{c}\text { Project } \\
\text { implementation }\end{array}$ & $\begin{array}{c}\text { Funding rate }(\%) \\
\text { Expenditure } \\
\text { compliance } \\
\text { Budget } \\
\text { adjustment rate } \\
(\%) \\
\text { Project quality } \\
\text { controllability } \\
\text { project progress } \\
\text { Schedule } \\
\text { adjustment range }\end{array}$ \\
\hline & Project Acceptance & $\begin{array}{c}\text { Project } \\
\text { completion rate } \\
\text { Fund utilization } \\
\text { rate }(\%) \\
\text { Achievement } \\
\text { appraisal }\end{array}$ \\
\hline
\end{tabular}

\subsubsection{Learning and growth dimensions}

The dimension of learning and growth requires companies to pay attention to the cultivation of employee abilities, stimulate their interest in learning new knowledge and new technologies, and form a strong and high-quality workforce, thereby improving the overall strength of the company to meet the ever-increasing requirements of customers. As far as the research in this article is concerned, the object of the research is scientific research projects, and the purpose of evaluation based on this dimension is twofold: First, whether the scientific research projects are helpful to the improvement of the scientific research ability of the participants. The specific indicators can be set as personnel training rate, Number of seminars, promotion of professional titles, etc.; second, whether the system, management experience and methods developed during the implementation of scientific research projects can be applied to other similar scientific research projects $^{[4]}$, that is, whether it can promote the improvement of scientific research project management system, Specific indicators can be set as team organization structure, project management experience and methods, 
personnel incentive system, etc. Specific indicators are shown in Table 4:

Table4. Performance indicators of the learning and growth dimension

\begin{tabular}{|c|c|c|}
\hline Dimension & Category & $\begin{array}{c}\text { Key Performance } \\
\text { Indicators }\end{array}$ \\
\hline & & Number of \\
seminars held \\
Personnel training \\
Learning and \\
\cline { 2 - 3 } growth & & rate (\%) \\
& & Promotion \\
\cline { 2 - 3 } & & Team organization \\
& Research Project & Project \\
& & management \\
& & experience and \\
& & methods \\
& & Staff incentive \\
& & system \\
\hline
\end{tabular}

\section{Screening and determining the performance evaluation indicators of scientific research projects based on the balanced score card}

Through the analysis of the performance evaluation indicators of scientific research projects in four dimensions, this paper initially constructs an indicator system. In order to ensure that the evaluation indicators conform to the actual environment as much as possible, the indicators need to be further screened and determined. This paper studies the questionnaires sent out to researchers who are on the front line of scientific research, so that they can score the existing indicators $(1,3,5,7,9)$, and the scores correspond to the degree of importance (not important, ordinary, important, more important, extremely important), and then filter and determine the indicators through numerical calculations.

A total of 20 experts and researchers who have been engaged in scientific research for a long time were selected for this study, 20 questionnaires were issued, and 20 were recovered. The expert positive coefficient (the ratio of experts participating in the evaluation to the total number of experts) is $100 \%$, and a coefficient greater than $70 \%$ can be considered the positive coefficient of experts is good, and the results of the consultation are credible. According to the feedback, the score obtained by each indicator is statistically processed, and its arithmetic mean value $\left(\bar{x}_{i}\right)$ is calculated. The specific calculation formula (1) is as follows, which $\bar{x}_{i}$ represents the arithmetic mean value of the $\mathrm{i}$-th indicator $(\mathrm{i}=1,2,3, \ldots, 37)$, which $x_{i j}$ represents the score of the $\mathrm{i}$-th index by the $\mathrm{j}$-th expert $(j=1,2,3, \ldots, n)$, and $n=20$ :

$$
\bar{x}_{i}=\frac{\sum_{j=1}^{n} x_{i j}}{n}
$$

The standard deviation $\left(\sigma_{i}\right)$ calculation formula $(2)$ is as follows, where $\sigma_{i}$ is the standard deviation of the i-th index $(i=1,2,3, \ldots, 37)$, and the other symbols have the same meaning as formula (1):

$$
\sigma_{i}=\sqrt{\frac{\sum_{j=1}^{n}\left(x_{i j}-\overline{x_{i}}\right)^{2}}{\mathrm{n}}}
$$

The calculation formula of the coefficient of variation $(\mathrm{Cv})$ is as follows (3), where $\bar{x}_{i}$ and $\sigma_{i}$ are the arithmetic mean and standard deviation mentioned above:

$$
C_{v}=\frac{x_{i}}{\sigma_{i}}
$$

Finally get the index screening reference information, as shown in Table 5:

\begin{tabular}{|c|c|c|c|}
\hline Index & $\begin{array}{l}\text { Arithmetic } \\
\text { mean }\left(\bar{x}_{i}\right)\end{array}$ & $\begin{array}{c}\begin{array}{r}\text { Standard } \\
\text { deviation }\end{array} \\
\left(\sigma_{i}\right)\end{array}$ & $\begin{array}{c}\text { Coefficient of } \\
\text { Variation } \\
\left(C_{v}\right)\end{array}$ \\
\hline Funding & 7.7 & 0.95 & 0.12 \\
\hline $\begin{array}{c}\text { Hardware/soft } \\
\text { ware } \\
\text { investment }\end{array}$ & 5.9 & 0.99 & 0.17 \\
\hline $\begin{array}{c}\text { Scientific } \\
\text { research } \\
\text { personnel } \\
\text { input }\end{array}$ & 8.2 & 0.98 & 0.12 \\
\hline $\begin{array}{c}\text { Number of } \\
\text { academic } \\
\text { papers }\end{array}$ & 6.3 & 0.95 & 0.15 \\
\hline $\begin{array}{c}\text { Number of } \\
\text { core } \\
\text { journals/confer } \\
\text { ences }\end{array}$ & 6.2 & 0.98 & 0.16 \\
\hline $\begin{array}{c}\text { Number of } \\
\text { monographs } \\
\text { published }\end{array}$ & 3.2 & 0.87 & 0.27 \\
\hline $\begin{array}{c}\text { Number of } \\
\text { national } \\
\text { patents }\end{array}$ & 5.4 & 0.80 & 0.15 \\
\hline research report & 6.0 & 1.00 & 0.17 \\
\hline $\begin{array}{l}\text { computer } \\
\text { software }\end{array}$ & 3.7 & 1.07 & 0.29 \\
\hline $\begin{array}{c}\text { New } \\
\text { product/new } \\
\text { equipment }\end{array}$ & 4.1 & 0.99 & 0.24 \\
\hline $\begin{array}{c}\text { Experimental } \\
\text { data }\end{array}$ & 3.8 & 0.97 & 0.26 \\
\hline $\begin{array}{l}\text { National Key } \\
\text { Laboratory }\end{array}$ & 3.7 & 1.11 & 0.30 \\
\hline $\begin{array}{l}\text { National Key } \\
\text { Discipline } \\
\text { Construction }\end{array}$ & 3.8 & 1.17 & 0.31 \\
\hline $\begin{array}{l}\text { Achievement } \\
\text { awards }\end{array}$ & 6.2 & 1.32 & 0.21 \\
\hline $\begin{array}{l}\text { Theoretical } \\
\text { innovation }\end{array}$ & 6.1 & 0.99 & 0.16 \\
\hline $\begin{array}{c}\text { Perfect } \\
\text { discipline } \\
\text { system }\end{array}$ & 5.3 & 1.45 & 0.27 \\
\hline $\begin{array}{l}\text { Technical test } \\
\text { success rate } \\
(\%)\end{array}$ & 5.4 & 1.36 & 0.25 \\
\hline $\begin{array}{l}\text { Technical } \\
\text { application } \\
\text { scope }\end{array}$ & 3.9 & 1.61 & 0.41 \\
\hline Technology & 6.0 & 1.48 & 0.24 \\
\hline
\end{tabular}

Table5. Reference information of performance evaluation indicators of scientific research projects 


\begin{tabular}{|c|c|c|c|}
\hline $\begin{array}{c}\text { conversion rate } \\
(\%)\end{array}$ & & & \\
\hline $\begin{array}{l}\text { Technological } \\
\text { advancement }\end{array}$ & 5.7 & 0.95 & 0.17 \\
\hline $\begin{array}{l}\text { Innovative } \\
\text { expected } \\
\text { results }\end{array}$ & 6.7 & 0.71 & 0.11 \\
\hline $\begin{array}{l}\text { Project plan } \\
\text { rationality }\end{array}$ & 6.8 & 0.60 & 0.09 \\
\hline $\begin{array}{c}\text { Funding rate } \\
(\%)\end{array}$ & 7.0 & 0.89 & 0.13 \\
\hline $\begin{array}{l}\text { Expenditure } \\
\text { compliance }\end{array}$ & 7.2 & 0.87 & 0.12 \\
\hline $\begin{array}{c}\text { Budget } \\
\text { adjustment } \\
\text { rate }(\%)\end{array}$ & 3.5 & 1.07 & 0.31 \\
\hline $\begin{array}{l}\text { Project quality } \\
\text { controllability }\end{array}$ & 3.8 & 0.98 & 0.26 \\
\hline $\begin{array}{l}\text { project } \\
\text { progress }\end{array}$ & 3.5 & 0.98 & 0.28 \\
\hline $\begin{array}{l}\text { Schedule } \\
\text { adjustment } \\
\text { range }\end{array}$ & 3.6 & 1.04 & 0.29 \\
\hline $\begin{array}{c}\text { Project } \\
\text { completion } \\
\text { rate }\end{array}$ & 8.8 & 0.60 & 0.07 \\
\hline $\begin{array}{c}\text { Fund } \\
\text { utilization rate } \\
(\%)\end{array}$ & 8.5 & 0.86 & 0.10 \\
\hline $\begin{array}{c}\text { Achievement } \\
\text { appraisal }\end{array}$ & 8.6 & 0.8 & 0.09 \\
\hline $\begin{array}{c}\text { Personnel } \\
\text { training rate } \\
(\%)\end{array}$ & 3.6 & 1.01 & 0.28 \\
\hline $\begin{array}{c}\text { Number of } \\
\text { seminars held }\end{array}$ & 3.5 & 1.01 & 0.29 \\
\hline Promotion & 3.7 & 0.95 & 0.26 \\
\hline $\begin{array}{c}\text { Team } \\
\text { organization } \\
\text { structure }\end{array}$ & 4.5 & 0.87 & 0.19 \\
\hline $\begin{array}{c}\text { Project } \\
\text { management } \\
\text { experience and } \\
\text { methods }\end{array}$ & 4.6 & 0.80 & 0.17 \\
\hline $\begin{array}{c}\text { Staff incentive } \\
\text { system }\end{array}$ & 4.8 & 0.87 & 0.18 \\
\hline
\end{tabular}

The selection of indicators in this paper refers to the commonly used boundary value method in the Delphi expert consultation method to select evaluation indicators $^{[5]}$. Based on the arithmetic mean and coefficient of variation of the score calculation by the expert on the importance of each indicator, the calculation The boundary value of the two, among which the calculation method of the boundary value of the arithmetic mean: "boundary value = mean-standard deviation", the index mean is higher than the boundary value is selected; the calculation method of the boundary value of the coefficient of variation: "boundary value $=$ Mean + standard deviation", the index's coefficient of variation is lower than the cutoff value. In order to avoid removing important indicators, in this study, only indicators that do not meet the requirements of the above two measurement scales are excluded, and only one indicator that does not meet the measurement scale is reserved to ensure the aforementioned indicator design principles. The index selection threshold table is as follows:

Table6. Index Screening Boundary Value Table

\begin{tabular}{cccc}
\hline & $\begin{array}{c}\text { Average } \\
\text { value }\end{array}$ & $\begin{array}{c}\text { Standard } \\
\text { deviation }\end{array}$ & $\begin{array}{c}\text { Critical } \\
\text { value }\end{array}$ \\
\hline Arithmetic & 5.39 & 1.66 & 3.73 \\
mean $\left(\bar{x}_{i}\right)$ & & 0.08 & 0.28 \\
$\begin{array}{c}\text { Coefficient of } \\
\text { Variation } \\
(\mathbf{C v})\end{array}$ & 0.20 & & \\
\hline
\end{tabular}

According to the above table, the indicators with the arithmetic mean less than or equal to 3.73 and the coefficient of variation greater than or equal to 0.28 in Table 5 are eliminated, namely "number of published monographs", "computer software", "national key laboratory", " Indicators such as "budget adjustment rate", "project progress", "planned progress adjustment range", "personnel training rate", and "number of seminars" are eliminated. Finally, the performance evaluation index system of scientific research projects based on the balanced score card is obtained as shown in the figure below: 


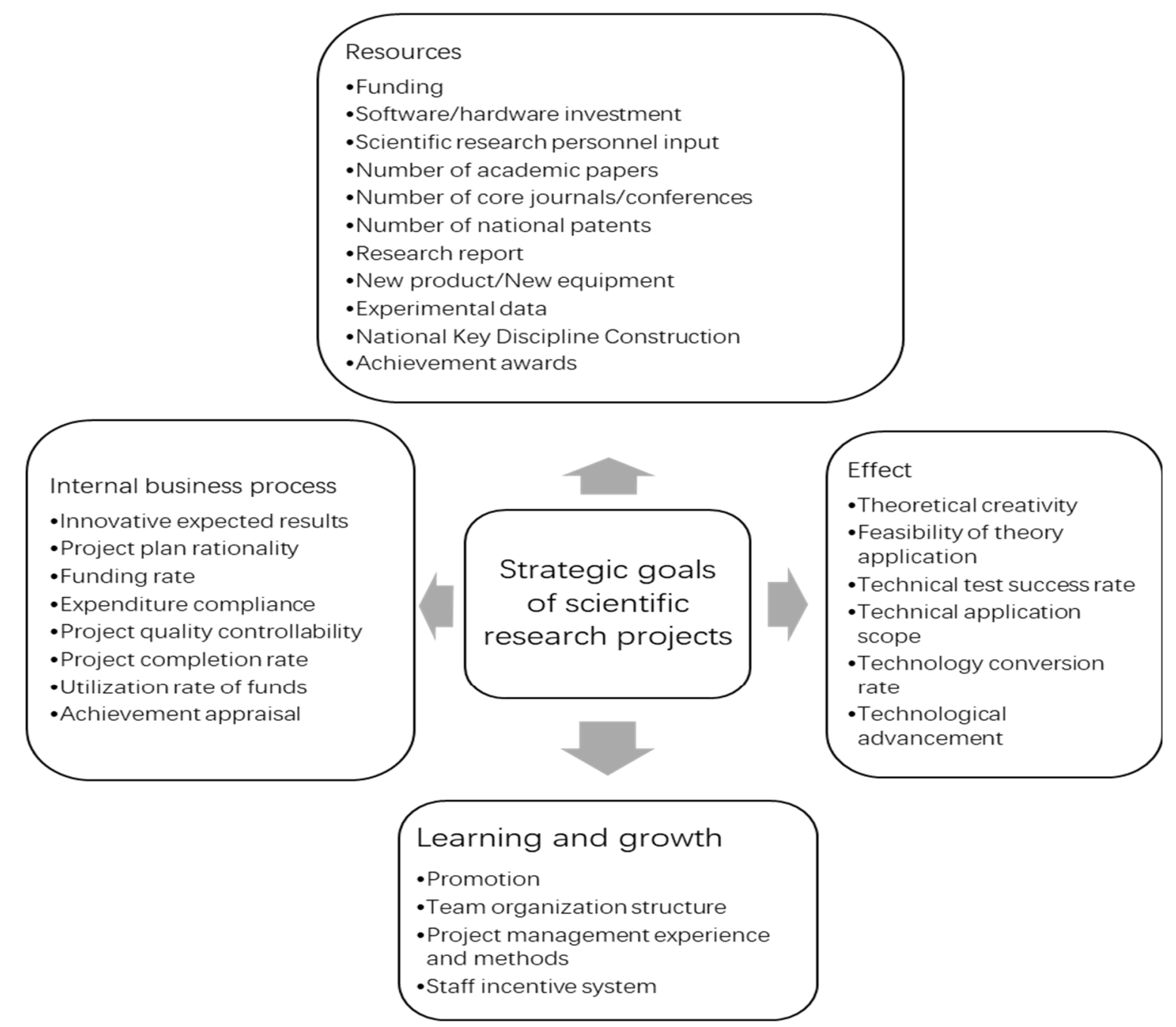

Fig 1. The performance evaluation index system of scientific research projects based on the balanced score card

\section{Conclusion}

Based on the core content of the balanced score card, this paper constructs the performance evaluation indicators of scientific research projects from the four dimensions of resources, effect, internal business processes, learning and growth, and selects the indicators through expert consultation to ensure the establishment of indicators. It is consistent with the actual work of scientific research projects. In the process of research, it was discovered that the evaluation index setting of scientific research projects is different from general scientific research projects. It is difficult to use common financial indicators in the economic market due to its innovative and uncertain characteristics. It is more dependent on technical indicators and academic indicators (such as the number of published papers) for evaluation. The research in this article is only the early stage of the performance evaluation of scientific research projects. The research work such as the weighting of indicators, the determination of evaluation methods and the improvement of the performance evaluation system needs further research.

\section{References}

1. Liu Na. Improving the research on project performance evaluation of scientific research institutes[J]. Accounting Learning, 2019(36).

2. Wang Haini. Research on the performance evaluation of the internal control management of scientific research funds in colleges and universities[J]. Friends of Accounting, 2020(01).

3. Xu Mengbo, Weng Yu dong, etc. Government budget performance indicator framework and indicator database construction research [M]. Beijing: People's Posts and Telecommunications Press, 2016: 114-138.

4. Zhou Wenyong, You Jianxin, Zheng Haiao. Theories and methods of performance evaluation of government-invested science and technology projects[M]. Beijing: Chemical Industry Press, 2009: 114-120.

5. Lu Yi mo. Research on the Performance Evaluation Index System of Colleges and Universities Based on AHP-fuzzy Method-Taking S Academy as an Example [J]. China Economic and Trade Guide (Secondary), 2020(10): 121-123. 